\title{
Eksperimentasi Model Pembelajaran Think Pair and Share (TPS) dengan Pendekatan Saintifik pada Materi Fungsi Ditinjau dari Interaksi Sosial Siswa
}

\author{
Heri Cahyono \\ Program Studi Pendidikan Matematika, STKIP Modern Ngawi \\ hericahyono@live.com
}

\begin{abstract}
ABSTRAK
Tujuan penelitian ini adalah untuk mengetahui manakah yang memberikan prestasi belajar matematika lebih baik pada model pembelajaran kooperatif tipe TPS dengan pendekatan saintifik, siswa dengan tingkat interaksi sosial tinggi, sedang, atau rendah pada materi pokok fungsi. Penelitian ini merupakan penelitian eksperimental semu. Populasinya adalah seluruh siswa kelas VIII SMP Negeri di Kabupaten Ngawi tahun pelajaran 2016/2017. Teknik pengambilan sampel menggunakan stratified cluster random sampling, sehingga diperoleh siswa pada SMP Negeri 3 Ngrambe, SMP Negeri 2 Paron, dan SMP Negeri 2 Widodaren sebagai sampel penelitian sebanyak 90 siswa. Instrumen pengumpulan data menggunakan tes prestasi belajar dan angket interaksi sosial siswa. Pengujian hipotesis menggunakan analisis variansi (anava) satu jalan sel tak sama. Kesimpulan penelitian ini adalah model pembelajaran kooperatif tipe TPS dengan pendekatan saintifik pada siswa tingkat interaksi sosial tinggi memberikan prestasi belajar matematika lebih baik dibandingkan dengan siswa tingkat interaksi sosial sedang dan rendah, serta prestasi belajar matematika siswa tingkat interaksi sosial sedang sama baiknya dibandingkan dengan siswa tingkat interaksi sosial rendah dalam memberikan prestasi belajar matematika pada materi pokok fungsi.
\end{abstract}

Kata kunci: Interaksi Sosial Siswa, TPS dengan Pendekatan Saintifik, Prestasi Belajar

\begin{abstract}
The purpose of this study is to find out which gives better mathematics learning achievement in the TPS type cooperative learning model with a scientific approach, students with high, medium, or low levels of social interaction on the subject matter of function. This research is a quasi-experimental study. The population is all eighth grade students of state junior high schools in Ngawi Regency 2016/2017 school year. The sampling technique uses stratified cluster random sampling, so that students are obtained at SMP Ngrambe 3, SMP Negeri 2 Paron, and SMP Negeri 2 Widodaren as a research sample of 90 students. Data collection instruments used achievement tests and student social interaction questionnaires. Hypothesis testing using analysis of variance (anava) one cell path is not the same. The conclusion of this study is the type of TPS cooperative learning model with a scientific approach to students with high levels of social interaction provides better mathematics learning achievement compared to students with moderate and low levels of social interaction, and mathematics learning achievement of students with moderate levels of social interaction as well compared to students with levels of interaction socially low in providing mathematics learning achievement on the subject matter of function.
\end{abstract}

Key words: Learning Achievement, Student Soscial Interaction, TPS with Saintific Approach

\section{Pendahuluan}

Pendidikan merupakan salah satu modal untuk mencapai kemajuan bangsa, pendidikan juga merupakan media pengembangan ilmu pengetahuan dan teknologi. Sehingga melalui pendidikan diharapkan dapat tercipta generasi baru yang lebih memiliki potensi dan dapat berkembang menjadi sumber daya manusia yang berkualitas. Sebagai ilmu dasar, matematika mempunyai peranan yang sangat penting terhadap perkembangan ilmu pengetahuan dan teknologi. Menurut Ignacio et al. (2006) learning mathematics has become a necessity for an individual's full development in today's complex society. Technological advances and the growing importance of the means of communication make it necessary for people to adapt to the new situations that are arising out of social change. Maksudnya adalah mempelajari matematika merupakan suatu kebutuhan bagi setiap individu saat ini, kemajuan teknologi dan 


\section{HERI CAHYONO}

Eksperimentasi Model Pembelajaran Think Pair Share (TPS)

semakin pentingnya sarana komunikasi membuat orang perlu untuk beradaptasi dengan situasi baru yang timbul dalam perubahan sosial.

Matematika adalah salah satu mata pelajaran yang harus dipelajari disekolah. Oleh karena itu peserta didik harus dapat menciptakan suasana pembelajaran yang menyenangkan pada saat pelajaran matematika. Proses belajar matematika akan terjadi dengan lancar apabila dilakukan secara kontinyu. Didalam proses belajar matematika, terjadi juga proses berpikir, karena seseorang dikatakan berpikir bila orang tersebut melakukan kegiatan mental dan orang yang belajar matematika harus melakukan kegiatan mental.

Pelajaran matematika sampai saat ini masih dianggap sebagai suatu momok yang menakutkan bagi siswa. Menurut Ignacio et al. (2006) despite its utility and importance, mathematics is perceived by most pupils as difficult, boring, not very practical, abstract, etc. Maksudnya adalah matematika merupakan ilmu yang penting dan oleh sebagian besar siswa matematika masih dianggap sulit, membosankan, tidak praktis dan abstrak, dengan demikian perlu dikembangkan dan digunakan inovasi-inovasi yang menarik untuk mengatasi permasalahan tersebut.

Kurikulum 2013 merupakan salah satu solusi untuk mengatasi masalah tersebut. Pada kurikulum 2013 pembelajaran kompetensi dilakukan dengan memperkuat proses pembelajaran dan penilaian autentik untuk mencapai kompetensi sikap, pengetahuan dan keterampilan. Penguatan proses pembelajaran dilakukan melalui pendekatan saintifik, yaitu pembelajaran yang mendorong siswa mampu dalam mengamati, menanya, mencoba/mengumpulkan data, mengasosiasi/menalar, dan mengkomunikasikan (Kemendikbud, 2013). Proses pembelajaran menyentuh tiga ranah, yaitu sikap, pengetahuan, dan keterampilan. Hasil belajar menggunakan penilaian autentik (Authentic Assessment) yaitu pengukuran yang bermakna secara signifikan atas hasil belajar peserta didik untuk ranah sikap, keterampilan, dan pengetahuan.

Pada kurikulum 2013 terdapat banyak perubahan dibanding dengan kurikulum sebelumnya yaitu KTSP, beberapa perubahan mendasar dari kurikulum 2006 ke kurikulum 2013 yaitu: a) Penataan pola pikir, b) Pendalaman dan perluasan materi, c) Penguatan proses, d) Penyesuaian beban, sedangkan elemen yang berubah antara lain: a) Standar kompetensi Lulusan, b) Standar isi, c) Standar proses, d) Standar penilaian. Kurikulum 2013 lebih menekankan pada dimensi pedagogik modern dalam pembelajaran, yaitu menggunakan pendekatan ilmiah/saintifik.

Melalui pendekatan tersebut diharapkan siswa memiliki kompetensi sikap, keterampilan, dan pengetahuan jauh lebih baik. Mereka akan lebih kreatif, inovatif, dan lebih produktif, sehingga nantinya mereka bisa sukses dalam menghadapi berbagai persoalan dan tantangan di zamannya, memasuki masa depan yang lebih baik, sehingga diharapkan dengan digunakannya kurikulum 2013 akan dapat meningkatkan kualitas pendidikan di Indonesia.

Kabupaten Ngawi merupakan sebuah kabupaten yang sedang berkembang sehingga prestasi belajar siswanya pun cenderung kurang dibandingkan dengan kabupaten yang lain di provinsi Jawa Timur. Hal ini dapat dilihat dari hasil Ujian Nasional tahun 2015 untuk mata pelajaran matematika yang menunjukkan urutan ke-35 dari 38 kabupaten/kota di Jawa Timur dengan nilai rata-rata 4,78 (BSNP, 2016). Hal ini menunjukkan bahwa prestasi belajar matematika Kabupaten Ngawi masih rendah dan perlu ditingkatkan lagi. 
Matematika merupakan salah satu mata pelajaran yang selalu ada pada setiap jenjang pendidikan. Pada materi pokok fungsi untuk siswa SMP Negeri di Kabupaten Ngawi menunjukkan nilai yang masih rendah. Data dari BSNP tahun 2013 sampai 2015 untuk materi fungsi dapat dilihat pada Tabel 1 .

Tabel 1. Daya Serap Materi Fungsi SMP Negeri di Kabupaten Ngawi

\begin{tabular}{cccc}
\hline \multirow{2}{*}{ Tahun } & Materi & \multicolumn{2}{c}{ Daya Serap } \\
\cline { 3 - 4 } & \multirow{2}{*}{$\begin{array}{c}\text { Menyelesaikan masalah yang } \\
\text { berkaitan dengan fungsi }\end{array}$} & $70,76 \%$ & $79,17 \%$ \\
\cline { 3 - 4 } & & $59,10 \%$ & $81,37 \%$ \\
\hline 2013 & & $43,94 \%$ & $63,69 \%$
\end{tabular}

Sumber: Pamer Ujian Nasional tahun 2013-2015

Dari Tabel 1.1 dapat diketahui bahwa prestasi belajar pada materi pokok fungsi dari tahun 2013 sampai tahun 2015 cenderung turun sehingga masih perlu ditingkatkan dan diperbaiki lagi. Ada banyak faktor yang mempengaruhi prestasi belajar siswa, salah satunya adalah model pembelajaran yang digunakan saat proses pembelajaran. Pada kurikulum 2013 proses pembelajaran menggunakan model pembelajaran yang menggunakan pendekatan saintifik. Berdasarkan pengamatan peneliti pada kurikulum KTSP masih banyak guru yang mengajar dengan mengunakan model pembelajaran secara individu dan tidak berkelompok, sedangkan tingkat interaksi sosial antar siswa ketika diluar pelajaran menunjukkan masih tergolong baik, sehingga dalam penelitian ini dipilih model pembelajaran yang menggunakan kerjasama antar siswa dalam proses pembelajaran, maka peneliti memilih model pembelajaran TPS (think pair and share) untuk digunakan dalam penelitian.

Menurut Ibe (2009) think pair share strategies engage students in thinking about their response first, and then allow students to discuss their ideas with a partner before sharing their ideas with the whole class. Maksudnya TPS melibatkan para siswa dalam berpikir tentang respon pertama mereka, kemudian memungkinkan siswa untuk mendiskusikan ide-ide mereka dengan pasangan sebelum membagikan ide-ide mereka di kelas. Menurut Lyman dalam Trianto (2007) bahwa model pembelajaran TPS merupakan suatu cara yang efektif untuk membuat variasi suasana pada pola diskusi kelas. Dengan asumsi bahwa diskusi membutuhkan pengaturan untuk mengendalikan kelas secara keseluruhan, dan prosedur yang digunakan dalam think pair and share dapat memberi siswa lebih banyak waktu berpikir untuk merespon dan saling membantu, sehingga diharapkan dengan menggunakan model pembelajaran TPS dapat membantu siswa yang mengalami kesulitan dalam memahami materi pelajaran.

Penelitian yang menggunakan model pembelajaran TPS adalah penelitian yang dilakukan oleh Budiastuti (2013) diperoleh hasil bahwa prestasi siswa yang diberi model pembelajaran TPS lebih baik daripada siswa yang diberi model pembelajaran konvensional. Penelitian lain juga dilakukan oleh Ofodu \& Lawal (2011) yang menyatakan bahwa: there was a significant effect of the Think-Pair-Share Method (TPS-M) and the Reciprocal Teaching Method (RTM) methods on reading comprehension of students of high, average and low performance levels. 


\section{HERI CAHYONO}

Eksperimentasi Model Pembelajaran Think Pair Share (TPS)

It was concluded that these methods were superior to the conventional method and therefore should be used in schools. Berarti terdapat pengaruh yang signifikan dari metode TPS (TPSM) dan metode pembelajaran timbal balik (RTM) pada siswa dengan pemahaman membaca tinggi, sedang, dan rendah. Disimpulkan bahwa metode ini lebih unggul daripada metode konvensional, oleh karena itu hendaknya digunakan di sekolah-sekolah.

Model pembelajaran kooperatif berkaitan dengan kerjasama antar teman dalam kelompok, sedangkan kerjasama antar teman atau hubungan antar siswa termasuk dalam kategori interaksi sosial siswa. Interaksi sosial menurut Shaw (Ali, 2004) merupakan suatu pertukaran antar pribadi yang masing-masing orang menunjukkan perilakunya satu sama lain dalam kehadiran mereka dan masing-masing perilaku mempengaruhi satu sama lain. Keberhasilan suatu pembelajaran tidak hanya ditentukan dari tingkat kecerdasan yang dimiliki dari masingmasing individu, namun juga ditentukan dari tingkat interaksi sosial antar individu karena pada proses pembelajaran siswa tidak selalu bisa bekerja sendiri dan cenderung berkelompok. Newman, Adeyemi (2008) menyatakan bahwa pembelajaran kooperatif didasarkan pada penciptaan, analisis dan struktur yang sistematis serta cara mengorganisasi interaksi sosial siswa di dalam kelas. Berdasarkan hal tersebut maka peneliti mengambil model pembelajaran kooperatif tipe TPS yang ditinjau dari tingkat interaksi sosial siswa.

Schutz (Doherty \& Colangelo, 1984) menyatakan bahwa setiap manusia memiliki tiga kebutuhan antarpribadi yang disebut dengan inklusi, kontrol dan afeksi. Asumsi dasar teori ini adalah bahwa manusia dalam hidupnya membutuhkan manusia lain (manusia sebagai makhluk sosial). Teori lain yang sejalan dengan teori tersebut adalah teori yang disampaikan oleh Mulder (2000) bahwa interaksi muncul dari dorongan untuk berkumpul, dan memenuhi kebutuhan akan afeksi, inklusi, dan kontrol. Indikator yang digunakan diambil dari dorongan pemenuhan akan kebutuhan afeksi, inklusi, dan kontrol, yaitu: a) aspek afeksi meliputi memberi perhatian kepada orang lain, disayang atau diperhatikan oleh teman dan memberikan pujian terhadap kelebihan orang lain, b) aspek inklusi meliputi menjalin hubungan dengan orang lain, bersikap terbuka dan menerima orang lain apa adanya dan partisipasi dalam aktivitas kelompok, c) aspek kontrol meliputi memberi pengarahan pada teman sebaya, menjadi pemimpin kelompok, mendapat petunjuk dari orang lain.

Berdasarkan paparan tersebut penelitian ini bertujuan untuk mengetahui manakah yang memberikan prestasi belajar matematika lebih baik pada model pembelajaran kooperatif tipe TPS dengan pendekatan saintifik, siswa dengan tingkat interaksi sosial tinggi, sedang, atau rendah pada materi pokok fungsi.

\section{Metode Penelitian}

Jenis penelitian ini adalah eksperimental semu. Populasi dalam penelitian ini adalah seluruh siswa kelas VIII SMP Negeri di Kabupaten Ngawi tahun pelajaran 2016/2017. Teknik pengambilan sampel dengan menggunakan stratified cluster random sampling. Berdasarkan teknik sampling yang digunakan diperoleh bahwa sampel-sampel yang digunakan adalah siswa SMPN 3 Ngrambe mewakili sekolah kategori tinggi, SMPN 2 Paron mewakili sekolah kategori sedang, dan SMPN 2 Widodaren mewakili sekolah kategori rendah.

Variabel bebas dalam penelitian ini adalah interaksi sosial siswa, sedangkan variabel terikatnya adalah prestasi belajar matematika. Metode pengumpulan data yang digunakan adalah metode angket, metode tes, dan metode dokumentasi. Metode angket dilakukan untuk memperoleh data interaksi sosial siswa dan metode tes digunakan untuk memperoleh data prestasi belajar matematika, sedangkan metode dokumentasi digunakan untuk memperoleh 
data sampel penelitian dan data kemampuan awal siswa sebelum dikenakan perlakuan dalam penelitian. Instrumen yang digunakan dalam penelitian ini berupa angket interaksi sosial dan tes prestasi belajar matematika pada materi fungsi yang sebelumnya telah diuji validitas dan reliabilitas instrumennya. Sebelum penelitian dilakukan, peneliti terlebih dahulu melakukan uji keseimbangan pada kelas yang dijadikan sampel penelitian. Selanjutnya dilakukan pengujian hipotesis dengan menggunakan uji analisis variansi satu jalan sel tak sama.

\section{Hasil dan Pembahasan}

Hasil uji keseimbangan dalam penelitian ini menggunakan uji analisis variansi satu jalan sel tak sama yang terangkum dalam Tabel 2.

Tabel 2. Rangkuman Analisis Variansi Satu Jalan Sel Tak Sama Uji Keseimbangan

\begin{tabular}{ccccccc}
\hline Sumber & $\boldsymbol{J K}$ & $\boldsymbol{d} \boldsymbol{k}$ & $\boldsymbol{R K}$ & $\boldsymbol{F}_{\boldsymbol{o b s}}$ & $\boldsymbol{F}_{\boldsymbol{\alpha}}$ & Keputusan \\
\hline Kelas & 13.8869 & 2 & 6.9434 & 1.4748 & 3,1052 & $H_{0}$ diterima \\
\hline Galat & 395.4852 & 84 & 4.7082 & - & - & \\
\hline Total & 409.3721 & 86 & - & - & - & \\
\hline
\end{tabular}

Berdasarkan Tabel 2 dapat dilihat $F_{\text {obs }}$ sebesar 1,4748 dan $F_{\alpha}$ sebesar 3,1052. Karena $F_{o b s}<$ $F_{\alpha}$ maka $H_{0}$ diterima, sehingga disimpulkan bahwa populasi mempunyai kemampuan awal yang sama (seimbang). Berdasarkan hasil dari uji anava satu jalan sel tak sama, maka sampel yang diambil telah memenuhi persyaratan untuk dilakukan penelitian. Hasil penelitian tersebut diuji kembali untuk mengetahui apakah tingkat interaksi sosial memberikan pengaruh signifikan atau tidak pada model pembelajaran TPS-saintifik.

Selanjutnya dilakukan uji hipotesis menggunakan anava satu jalan dengan sel tak sama. Hasil uji anava satu jalan dengan sel tak sama terangkum dalam Tabel 3.

Tabel 3. Rangkuman Analisis Variansi satu Jalan Sel Tak Sama Uji Hipotesis

\begin{tabular}{ccccccc}
\hline Sumber & $\boldsymbol{J K}$ & $\boldsymbol{d}$ & $\boldsymbol{R K}$ & $\boldsymbol{F}_{\boldsymbol{o b s}}$ & $\boldsymbol{F}_{\boldsymbol{a}}$ & Keputusan \\
\hline Amatan & 5727.1693 & 2 & 2863.5847 & 17.5691 & 3.1154 & $H_{0}$ ditolak \\
\hline Galat & 12550.2368 & 77 & 162.9901 & - & - & \\
\hline Total & 18277.4061 & 78 & - & - & - & \\
\hline
\end{tabular}

Dari hasil perhitungan $F_{o b s}>F_{\alpha}$ maka keputusan ujinya adalah $H_{0}$ ditolak, sehingga diperoleh kesimpulan bahwa terdapat perbedaan pengaruh tingkat interaksi sosial siswa terhadap prestasi belajar matematika siswa. Karena hipotesis ditolak, diperlukan uji lanjut pasca anava yakni uji komparasi ganda dengan metode Scheffe'. Sebelum dilakukan uji komparasi ganda 
tersebut, terlebih dahulu dihitung rerata setiap kolomnya. Hasil perhitungan rerata pada setiap kolom tersebut disajikan dalam Tabel 4.

Tabel 4. Rerata Prestasi Belajar Matematika

\begin{tabular}{cccc}
\hline \multirow{2}{*}{ Model Pembelajaran } & \multicolumn{3}{c}{ Kategori Interaksi Sosial } \\
\cline { 2 - 4 } & Tinggi & Sedang & Rendah \\
\hline TPS-Saintifik & 76.6662 & 57.9307 & 55.9772 \\
\hline
\end{tabular}

Tabel 4 digunakan untuk melihat rerata pada masing-masing kategori interaksi sosial siswa apabila dari perhitungan uji komparasi ganda dinyatakan terdapat perbedaan yang signifikan. Hasil uji anava satu jalan sel tak sama menunjukkan $H_{0}$ ditolak, sehingga perlu dilakukan uji komparasi ganda. Rangkuman hasil uji komparasi ganda disajikan pada Tabel 5.

Tabel 5. Rangkuman Komparasi Ganda

\begin{tabular}{cccc}
\hline $\boldsymbol{H}_{\boldsymbol{0}}$ & $\boldsymbol{F}_{\boldsymbol{o b s}}$ & $\boldsymbol{F}_{\boldsymbol{a}}$ & Keputusan Uji \\
\hline$\mu_{1}=\mu_{2}$ & 26.2311 & 6.2307 & $H_{0}$ ditolak \\
\hline$\mu_{2}=\mu_{3}$ & 0.3452 & 6.2307 & $H_{0}$ diterima \\
\hline$\mu_{1}=\mu_{3}$ & 32.4404 & 6.2307 & $H_{0}$ ditolak \\
\hline
\end{tabular}

Berdasarkan Tabel 5 diketahui terdapat perbedaan prestasi belajar matematika siswa dengan interaksi sosial tinggi, sedang, dan rendah. Sesuai dengan hasil uji komparasi ganda dengan metode Scheffe' antara $\mu_{1}$ dan $\mu_{2}, H_{0}$ ditolak, dengan memperhatikan reratanya dapat disimpulkan bahwa pada model pembelajaran kooperatif tipe TPS dengan pendekatan saintifik, prestasi belajar matematika siswa dengan interaksi sosial tinggi lebih baik dibandingkan siswa dengan interaksi sosial sedang. Hasil penelitian dari Siti Amirah Budiastuti [10] diperoleh hasil bahwa prestasi siswa yang diberi model pembelajaran TPS lebih baik daripada siswa yang diberi model pembelajaran konvensional. Penelitian lain juga dilakukan oleh Ofodu \& Lawal [9] yang menyatakan bahwa "there was a significant effect of the Think-Pair-Share Method (TPS-M) and the Reciprocal Teaching Method (RTM) methods on reading comprehension of students of high, average and low performance levels" yang berarti terdapat pengaruh yang signifikan dari metode TPS (TPS-M) dan metode pembelajaran timbal balik (RTM) pada siswa dengan pemahaman membaca tinggi, sedang, dan rendah. Disimpulkan bahwa metode ini lebih unggul daripada metode konvensional. Dari beberapa penelitian tersebut turut menguatkan bahwa TPS merupakan model pembelajaran baik untuk digunakan, karena model pembelajaran kooperatif tipe TPS merupakan pembelajaran individu yang dibantu dengan berkelompok, sehingga pemahaman secara individu sangat ditekankan pada model ini, terlebih jika dipadukan dengan pendekatan saintifik. Pada siswa dengan tingkat interaksi sosial tinggi jika dikenai model pembelajaran kooperatif tipe TPS dengan pendekatan saintifik diskusi dapat berjalan dengan baik karena setiap anggota kelompok dapat mengutarakan pendapat mereka dengan baik, sedangkan pada 
siswa dengan tingkat interaksi sosial sedang dan rendah diskusi yang dilakukan dengan berpasangan kurang berjalan dengan baik, karena pembelajaran dilakukan dengan pendekatan saintifik siswa cenderung bersikap pasif serta kurang bisa mengikuti pembelajaran dengan baik.

Hasil uji komparasi ganda antara $\mu_{2}$ dan $\mu_{3}, H_{0}$ diterima, dengan memperhatikan reratanya dapat disimpulkan bahwa pada model pembelajaran kooperatif tipe TPS dengan pendekatan saintifik, prestasi belajar matematika siswa dengan interaksi sosial sedang sama baiknya dengan siswa dengan interaksi sosial rendah. Pada siswa dengan tingkat interaksi sosial sedang pada tahapan Think, Pair, Share kurang berjalan dengan optimal, hal ini dimungkinkan karena kurang akuratnya data pada saat siswa mengisi angket interaksi sosial siswa, sehingga mengakibatkan ketidaksesuaian antara kelompok dan tingkat interaksi sosial siswa.

Hasil uji komparasi ganda antara $\mu_{1}$ dan $\mu_{3}, H_{0}$ ditolak, dengan memperhatikan reratanya dapat disimpulkan bahwa pada model pembelajaran kooperatif tipe TPS dengan pendekatan saintifik, prestasi belajar matematika siswa dengan interaksi sosial tinggi lebih baik dibandingkan siswa dengan interaksi sosial rendah. Hal tersebut dikarenakan pada siswa dengan tingkat interaksi sosial tinggi jika dikenai model pembelajaran kooperatif tipe TPS dengan pendekatan saintifik diskusi dapat berjalan dengan baik karena setiap anggota kelompok dapat mengutarakan pendapat mereka dengan baik, sedangkan pada siswa dengan tingkat interaksi sosial sedang dan rendah diskusi yang dilakukan dengan berpasangan kurang berjalan dengan baik, karena pembelajaran dilakukan dengan pendekatan saintifik siswa cenderung bersikap pasif serta kurang bisa mengikuti pembelajaran dengan baik.

\section{Simpulan}

Berdasarkan hasil analisis dan pembahasan yang telah diuraikan sebelumnya, dapat disimpulkan pembelajaran dengan menggunakan model pembelajaran kooperatif tipe TPS dengan pendekatan saintifik, prestasi belajar matematika siswa tingkat interaksi sosial tinggi lebih baik dibandingkan dengan siswa tingkat interaksi sosial sedang dan rendah dalam memberikan prestasi belajar matematika pada materi pokok fungsi, sedangkan prestasi belajar matematika siswa tingkat interaksi sosial sedang sama baiknya dengan siswa tingkat interaksi sosial rendah dalam memberikan prestasi belajar matematika pada materi pokok fungsi.

\section{Daftar Pustaka}

Adeyemi, B. A. (2008). Effects of cooperative learning and problem-solving strategies on Junior Secondary School Students' Achievement in Social Studies. Electronic Journal of Research in Educational Psychology, 6(16), 691-708.

Badan Standar Nasional Pendidikan (BSNP). (2016). Laporan Hasil Ujian Nasional Tahun Pelajaran 2015/2016.

Doherty, W.J \& Colangelo, N. (1984). The Family Firo Model: A Modest Proposal for Organizing Family Treatment. Journal of Marital and Family Therapy, 10(1), 19-29.

Ibe, H. N. (2009). Metacognitive Strategies on Classroom Participation and Student Achievement in Senior Secondary School Science Classrooms. Science Education International, 20(1/2), 25-31.

Ignacio, N.G., Blanco Nieto, L.J. \& Barona, E.G. (2006). The Affective Domain In Mathema Tics Learning. International Electronic Journal of Mathematics Education, $1(1), 16-32$.

Kemendikbud. (2013). Permendikbud No 65 Tahun 2013. Kemendikbud. Jakarta. 
Ali, M. (2004). Psikologi Remaja. Bumi Aksara. Jakarta.

Mulder, N. (2000). Individu, Masyarakat, dan Sejarah. Kanisius. Yogyakarta.

Ofodu, G. O. \& Lawal, R. A. (2011). Cooperative Instructional Strategies and Performance Levels of Students in Reading Comprehension. International Journal of Emerging Sciences, 3(2), 103-107.

Budiastuti, S. A. (2013). Eksperimentasi Model Pembelajaran Kooperatif Think Pair Share dan Team Assisted Individualization Pada Materi Trigonometri Ditinjau Dari Minat Belajar Matematika Siswa SMK di Kabupaten Ponorogo Tahun Pelajaran 2011/2012. Tesis: Universitas Sebelas Maret Surakarta.

Trianto. (2007). Model-model Pembelajaran Inovatif Berorientasi Kontruktivistik. Prestasi Pustaka. Jakarta. 